Habib Safillah Akbariski: Permainan Bunyi dalam Penciptaan Humor Komik...

\title{
PERMAINAN BUNYI DALAM PENCIPTAAN HUMOR KOMIK @TAHILALATS DI INSTAGRAM
}

\author{
Sound Combinations in Humor Construction of Instagram's @Tahilalats \\ Habib Safillah Akbariski \\ Universitas Sebelas Maret \\ Jalan Ir. Sutami No. 36, Surakarta, Indonesia \\ Pos-el: habibsafillah@gmail.com
}

Naskah masuk: 28 Maret 2020, disetujui: 6 Juni 2020, revisi akhir: 21 Juni 2020

\begin{abstract}
Abstrak
Manusia disebut sebagai homo ludens yang artinya manusia adalah seorang pemain, termasuk memainkan bahasa secara kreatif dalam pelbagai situasi dan kondisi. Dalam hal ini, permainan bahasa yang dimaksud adalah permainan bunyi yang dimanfaatkan untuk menciptakan humor. Penelitian ini bertujuan untuk mendeskripsikan empat hal. Pertama, teknik permainan bunyi yang digunakan dalam membangun humor komik Tahilalats. Kedua, cara bunyi tersebut membangun humor dalam komik @Tahilalats. Ketiga, interpretasi penggunaan teknik permainan bunyi. Keempat, memaparkan model tuturan dalam komik @Tahilalats. Metode yang digunakan dalam penelitian ini adalah deskriptif kualitatif. Hasil penelitian ini menunjukkan bahwa dari 90 edisi komik @Tahilalats yang dianalisis terdapat 129 data permainan bunyi. Teknik permainan bunyi dalam komik @Tahilalats terdiri dari 10 jenis teknik yang apabila dipecah dapat menjadi 15 teknik. Proses bunyi dalam membangun humor bergantung pada masing-masing teknik yang diterapkan dalam komik. Interpretasi data menunjukkan bahwa teknik substitusi merupakan teknik yang paling banyak dimanfaatkan dalam komik @Tahilalats. Model tuturan dalam komik ini dirumuskan berdasarkan teori SPEAKING oleh Dell Hymes dengan memanfaatkan aspek ends, act, dan key. Komik @Tahilalats memanfaatkan aspek verbal-nonverbal dan bunyi segmental-suprasegmental dalam penciptaan humor dan tuturan.
\end{abstract}

Kata kunci: permainan bunyi; tuturan; humor; komik; tahilalats.

\begin{abstract}
Mankind called as homo ludens means a player who plays the game, it is included creatively playing the language in certain terms and conditions. Language game refers to the sound change for the sake of humor. This research aims to define four points. Firstly, sound change techniques build humorous materials in @ Tahilalats comic. Secondly, identifying the process of the sound builds the humorous materials in @ Tahilalats comic. Thirdly, interpretating the use of language games' technique. Lastly, explaining the type of information in @ Tahilalats comic. This research use qualitative description research as its method. The result shows that there are 129 sound change data from 90 editions of @ Tahilalats comic. The techniques of @ Tahilalats comic consisted of 10 types which will be differed into 15 techniques. The process of humor building depends on each type of techniques which are applied in the comic. The data interpretation shows substitution technique is the most common technique used in the @ Tahilalats comic. Information model in this comic is formulated into SPEAKING theory by Dell Hymes included aspects; ends; act; and key. @ Tahilalats comic utilizes verbal-nonverbal information and segmental-suprasegmental sound in humor and information building.
\end{abstract}

Keywords: sound change; information; humor, comic, tahilalats. 
Habib Safillah Akbariski: Permainan Bunyi dalam Penciptaan Humor Komik...

\section{Pendahuluan}

Fungsi utama bahasa adalah sebagai alat komunikasi dalam masyarakat. Brown dan Yule (1983, hal. 1) merumuskan dua fungsi utama bahasa, yakni transaksional dan interaksional. Sependapat dengan hal tersebut, Holmes (2006, hal. 275) menyatakan bahwa bahasa memiliki fungsi referensial dan fungsi afektif. Fungsi referensial merujuk pada tujuan menyampaikan informasi (pesan), sedangkan fungsi afektif bertujuan memantapkan dan memelihara hubungan sosial. Untuk menjalankan fungsi tersebut, manusia harus memiliki keterampilan berbahasa. Selanjutnya, fungsi tersebut dijalankan dalam berbagai lingkungan, tingkatan, dan kepentingan yang bermacam-macam, termasuk dalam kegiatan humor.

Dalam kehidupan sehari-hari, humor dianggap lucu dan membuat senang penikmatnya. Wijana (1995, hal. 4) berpendapat bahwa indikator yang paling jelas untuk mengidentifikasi seseorang menikmati suatu humor ialah tersenyum atau tertawa. Akan tetapi, perlu dipahami bahwa tidak semua aktivitas tersenyum atau tertawa merupakan indikasi bahwa seseorang tengah menikmati humor.

Manusia sebagai makhluk individu dan sosial yang hidup dalam masyarakat sering melakukan aktivitas bercanda, tertawa, berhumor, dan lainnya. Konteks komunikasi menjadi penting karena memengaruhi aktivitas komunikasi manusia. Dengan demikian, sebagian besar manusia hidup memerlukan humor dalam kehidupan sehari-hari.

Kelucuan yang didapatkan dari berhumor dibutuhkan seseorang untuk menghibur diri. Widjaja (2003) berpendapat bahwa dalam proses pertahanan hidupnya, kebutuhan manusia terhadap humor merupakan kebutuhan mutlak (Rahmanadji, 2007, hal. 213). Oleh karena itu, keberadaan humor dalam interaksi komunikasi manusia sangat penting. Hal ini didukung oleh banyaknya konten di media sosial Instagram yang menghadirkan unsur humor.

Hendarto (1990) menjelaskan bahwa kebutuhan manusia terhadap humor telah ada sejak manusia masih masa kanak. Menurut Hendarto, hal tersebut dapat tergambarkan dari perilaku ibu yang sering menirukan laku binatang, mengeluarkan bunyi aneh, dan memperagakan hal-hal yang tidak masuk akal untuk merangsang agar anak tertawa. Kebutuhan dan kegembiraan akan humor itu sudah melekat ketika sang anak beranjak dewasa. Berdasarkan hal tersebut, humor bermula sejak manusia masih dalam masa kanak dan bunyi merupakan salah satu aspek penciptaan humor paling awal.

Bell dan Pomerantz (2016, hal. 22) berpendapat bahwa humor merupakan kasus permainan bahasa atau wujud kreativitas dalam penggunaan bahasa. Manusia disebut sebagai homo ludens yang artinya manusia merupakan seorang pemain, termasuk memainkan bahasa secara kreatif dalam pelbagai situasi dan kondisi. Martin (2007, hal. 11) berpendapat bahwa humor yang terjadi dalam interaksi sosial dapat dibagi menjadi tiga kategori, yaitu (1) lelucon, anekdot yang dikemas dengan lucu dan dihapal dan disebarkan ke orang lain; (2) humor-percakapan spontan, yang diciptakan secara sengaja oleh individu selama interaksi sosial berlangsung, dapat berupa verbal dan nonverbal; dan (3) humor aksidental atau tanpa disengaja.

Ada tiga cara memainkan bahasa dalam menciptakan wacana rekreatif atau sejenisnya (Bergson dalam Hidayah, 2012, hal. 49). Ketiga cara itu adalah repetisi (pengulangan), inversi (pembalikan), dan interferensi resiprokal (usaha-usaha untuk memadukan nama-nama tempat dengan rekayasa padanan atau terjemahan dalam bahasa Indonesia). Wijana (dalam Hidayah, 2012, hal. 48) berpendapat bahwa wacana bersandar pada permainan bahasa atau penyimpangan fungsi pragmatik atau informatif. Berdasarkan pernyataan tersebut, salah satu aspek linguistik yang seringkali dimanfaatkan dalam penciptaan humor ialah permainan bunyi (fonologi). Pradopo dkk. (dalam Wijana, 1995) menyatakan bahwa penyimpangan bunyi sebagai salah satu penciptaan humor. Menurut Pradopo, penyimpangan bunyi dalam berhumor bukanlah sekadar penyimpangan biasa, melainkan penyimpangan yang menunjukkan inovasi dominan dalam pikiran ke dalam tuturan yang wajar. 
Habib Safillah Akbariski: Permainan Bunyi dalam Penciptaan Humor Komik...

Hampir semua orang menghadapi situasi lucu, cerita lucu, bahkan pikiran lucu dalam kehidupan sehari-hari. Terlebih, fungsi humor sangat beragam. Martin (2007: 15) mengelompokkan fungsi humor ke dalam tiga kategori, yaitu memberikan manfaat kognitif dan sosial dari emosi positif kegembiraan, menggunakan humor untuk komunikasi dan pengaruh sosial, dan untuk meringankan dan mengatasi ketegangan atau stres.

Humor menjadi penting karena tidak luput dari perspektif media sosial di Indonesia, khususnya pengguna Instagram. Signifikansi dapat diamati dari hadirnya beragam akun Instagram yang mengusung nuansa humor. Salah satu akun Instagram bernuansa humor adalah @Tahilalats.

@Tahilalats atau yang dikenal juga sebagai Mind Blowon merupakan sebuah komik daring berbahasa Indonesia yang dibuat, ditulis, dan diilustrasikan oleh Nurfadli Mursyid. Pertama kali dipublikasikan lewat akun @Tahilalats di Instagram pada tahun 2014. Komik ini sudah memiliki 3,5 juta pengikut di Instagram dengan total unggahan 1.960 . Komik harian ini memiliki ciri khas empat panel dalam sekali unggah. @Tahilalats juga ada di Line Webtoon dan media sosial lain seperti Twitter dan Facebook. Selain itu, @Tahilalats juga memiliki situs tersendiri dengan alamat https://www.Tahilalats.com/.

@Tahilalats bergenre kehidupan seharihari yang cenderung memiliki plot twist sulit ditebak oleh pembaca. Komik ini memanfaatkan tiga aspek dalam menciptakan humor, yaitu aspek gambar, bahasa, dan konteks. Aspek bahasa dalam komik ini memanfaatkan fitur bahasa, baik secara morfologi, fonologi, maupun semantik.

Komik @Tahilalats mengusung istilah mind blowon yang merupakan pelesetan dari mind blown. Blowon merupakan permainan bunyi dari beloon, bahasa Indonesia kasar untuk bodoh. Selain dalam istilah, @Tahilalats banyak memanfaatkan aspek bunyi dalam penciptaan humor.

Kurniawan (2018) pernah melakukan penelitian mengenai penciptaan humor dalam komik setrip Tahilalats di Webtoon. Hasil dari penelitian tersebut ialah ditemukan adanya dua aspek penciptaan humor, yaitu aspek bahasa dan logika. Aspek bahasa dalam komik @Tahilalats meliputi teknik kesalahpahaman, permainan bunyi, ironi, dan omong kosong. Penelitian yang dilakukan oleh Kurniawan tidak secara spesifik menjelaskan pemanfaatan aspek fonologis dalam komik @Tahilalats. Permainan bunyi yang ditemukan dalam penelitian tersebut hanya menjelaskan jenis permainan tiruan bunyi. Oleh karena itu, penulis tertarik mengkaji lebih mendalam mengenai permainan aspek fonologis dalam penciptaan humor @Tahilalats.

Nurul Fatonah (2017) pernah meneliti permainan bahasa dalam wacana humor pada akun meme Comic Indonesia di Instagram. Penelitian tersebut berfokus pada permainan bahasa bidang fonologi, morfologi, dan semantik. Dalam bidang fonologi, indikator yang dikaji oleh Nurul Fatonah, yaitu: (1) reduksi, penghilangan bunyi fonemis yang dapat diklasifikasikan menjadi tiga bentuk, yaitu aferesis, apokop, dan sinkop; (2) Adisi, perubahan bunyi dengan menambahkan bunyi tertentu yang dapat diklasifikasikan menjadi tiga jenis, yaitu protesis, epentesis, dan paragog; dan (3) substitusi bunyi, proses atau hasil dalam penggantian unsur bunyi.

Sukardi dkk. (2019) juga meneliti terkait permainan bunyi dalam akun meme Comic. Penelitian tersebut berangkat dari pendapat Wijana yang merumuskan lima teknik permainan bunyi dalam penciptaan humor, yaitu teknik substitusi, teknik permutasi, teknik penyisipan, teknik penambahan, dan teknik pelepasan. Sukardi dkk. (2019) dalam penelitian tersebut menemukan ada 10 teknik permainan bunyi yang dimanfaatkan dalam penciptaan humor, yaitu teknik substitusi, teknik penyisipan, teknik pelepasan, teknik pemberian jeda, teknik permutasi, teknik penambahan, teknik pemertahanan bunyi, teknik penghilangan jeda, teknik perubahan jeda, dan teknik pemanjangan bunyi.

Penelitian ini diharapkan mampu memberikan manfaat secara teoretis untuk menambah wawasan ilmu lingusitik, khususnya mengenai pemanfaatan bunyi dalam penciptaan humor. Penelitian ini 
Habib Safillah Akbariski: Permainan Bunyi dalam Penciptaan Humor Komik...

bertujuan untuk mendeskripsikan tiga hal. Pertama, teknik permainan bunyi yang digunakan dalam membangun humor komik @Tahilalats. Kedua, cara bunyi tersebut membangun humor dalam komik @Tahilalats. Ketiga, menginterpretasi penggunaan teknik permainan bunyi dalam proses penciptaan humor @Tahilalats. Keempat, memaparkan model tuturan dalam komik @Tahilalats.

\section{METODE PENELITIAN}

Penelitian ini merupakan jenis penelitian deskriptif kualitatif. Penelitian kualitatif adalah penelitian yang bermaksud untuk memahami fenomena yang dialami oleh subjek penelitian, misalnya perilaku, persepsi, motivasi, tindakan, dan lain-lain secara holistik dan dengan cara mendeskripsikan dalam bentuk kata-kata dan bahasa. Penelitian kualitatif meletakkan suatu konteks khusus yang alamiah dan dengan memanfaatkan berbagai metode alamiah (Moleong, 2005, hal. 6). Metode deskriptif digunakan karena penelitian ini adalah penelitian permainan bunyi dalam penciptaan humor @Tahilalats. Penelitian ini disebut sebagai penelitian deskriptif karena data berupa kata dan gambar.

Penelitian ini mendeskripsikan pemanfaatan aspek bunyi dalam penciptaan humor komik @Tahilalats. Sumber data penelitian ini adalah unggahan di akun Instagram @Tahilalats edisi April 2015-Januari 2020. Subjek penelitian ini adalah 90 edisi komik setrip @Tahilalats di Instagram. Objek penelitian ini adalah aspek fonologis yang terdapat dalam tuturan pada komik @Tahilalats. Terdapat 129 data dalam penelitian ini.

Pengumpulan data menggunakan teknik dokumentasi. Teknik ini dilakukan dengan cara menangkap layar dari data penelitian yang akan dianalisis. Selanjutnya, data dikategori berdasar aspek khusus dari permainan fonologis. Kemudian, data diolah, dikaji, dan disajikan dengan detail.

Analisis data penelitian ini dilakukan melalui kegiatan studi pustaka, inventarisasi data, identifikasi data, dan pemaknaan data.

\section{HASIL DAN PEMBAHASAN}

Hasil keseluruhan data permainan fonologis dalam penciptaan humor komik @Tahilalats di Instagram dari 90 komik berjumlah 129 data permainan bunyi. Permainan bunyi yang ditemukan dalam komik terdapat dalam Tabel 1 sebagai berikut.

Tabel 1

Sajian Hasil Teknik Permainan Bunyi No. Teknik Permainan Bunyi Jumlah

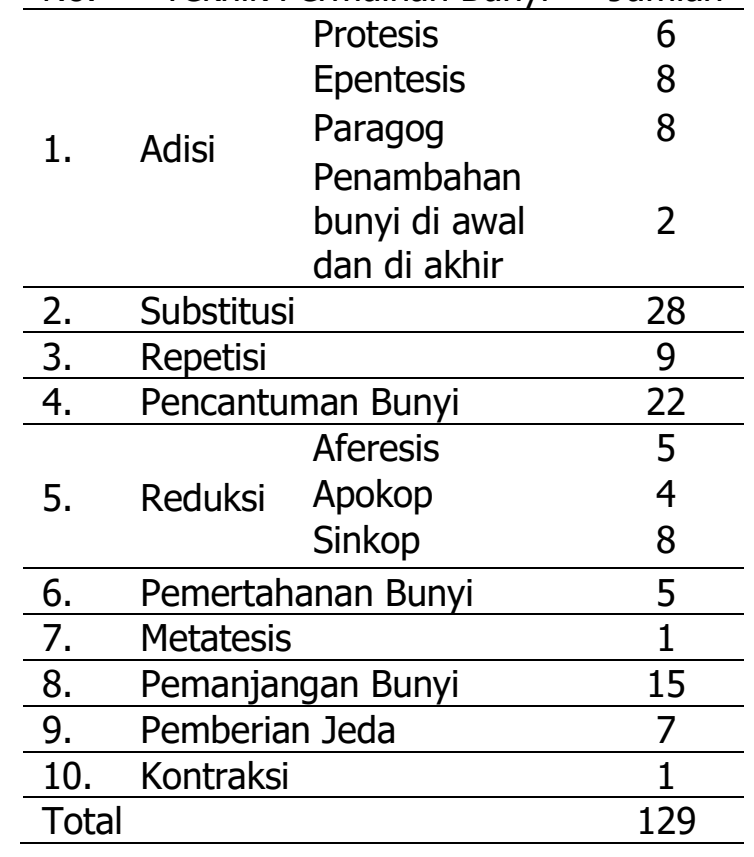

\subsection{Adisi}

Gejala adisi ialah perubahan yang terjadi dalam suatu tuturan karena penambahan fonem (Muslich, 2009, hal. 106). Fauzan (2017) dalam penelitian mengenai gejala bahasa prokem berpendapat bahwa gejala adisi terbagi menjadi tiga, yaitu protesis, epentesis, dan paragog. Akan tetapi, dalam penelitian ini ditemukan gejala penambahan bunyi di awal dan akhir kata sehingga terdapat empat gejala adisi, yakni protesis, epentesis, paragog, dan penambahan bunyi di awal dan akhir.

\subsubsection{Protesis}

Penambahan atau pembubuhan bunyi di awal kata disebut protesis (Badudu, 1985, hal. 63). Hal tersebut sependapat dengan yang disampaikan Keraf (1984, hal. 136) bahwa protesis adalah proses suatu kata mendapat tambahan satu fonem atau lebih pada awal kata. Contoh kata yang mengalami protesis adalah mas menjadi emas, tik menjadi ketik. 
Berikut ini disajikan data hasil penelitian beserta hasil analisis.

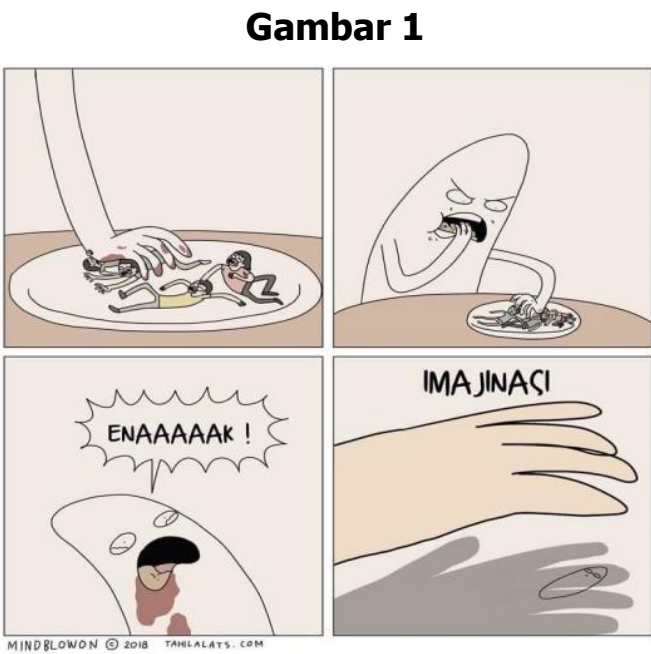

Konteks gambar di atas adalah memvisualisasikan sebutir nasi yang memakan orang-orang. Sekumpulan orang tersebut diletakkan di atas piring. Komik edisi ini membalikkan peran orang yang biasanya memakan nasi menjadi nasi yang memakan orang. Oleh karena hal tersebut tidak mungkin, maka disebut sebagai imajinasi. Efek humor terjadi di bagian akhir dengan menambahan bunyi /imaji/ di depan kata /nasi/.

Imajinasi dalam KBBI (2016) memiliki arti daya pikir untuk membayangkan (dalam angan-angan) atau menciptakan gambar (lukisan, karangan, dan sebagainya) kejadian berdasarkan kenyataan atau pengalaman seseorang. Secara sederhana, imajinasi dapat diartikan sebagai khayalan. Penambahan bunyi /imaji/ sebelum kata /nasi/ merupakan pengaplikasian pemanfaatan permainan bunyi dalam penciptaan humor.
Gambar2

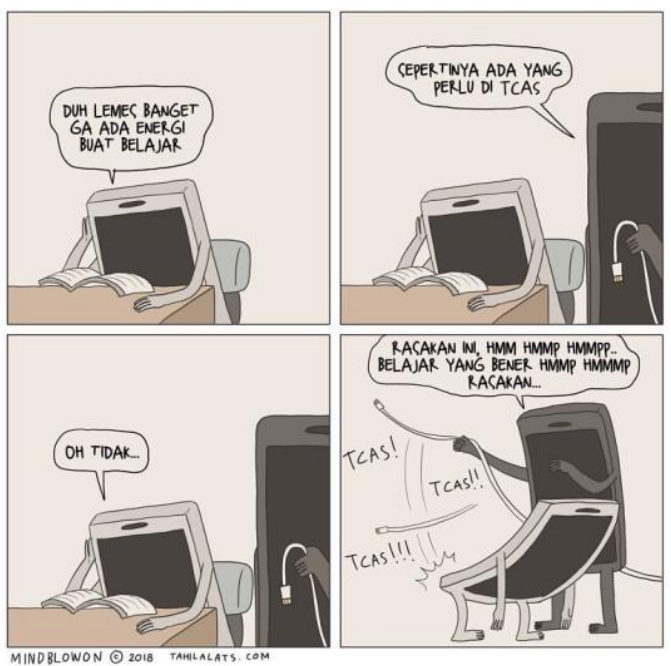

Gawai Putih: Duh, lemes banget ga ada energi buat belajar.

Gawai Hitam: Sepertinya ada yang perlu di tcas.

Gawai Putih: Oh tidak...

Gawai Hitam: Rasakan ini, hmm hmmp hmmpp... Belajar yang bener hmmp hmmmp rasakan...

Pada gambar di atas, terdapat penambahan bunyi /t/ setelah kata /cas/. Penambahan bunyi /t/ pada percakapan sepertinya ada yang perlu di tcas akan memberikan efek pertanyaan dalam benak pembaca karena percakapan yang terjadi adalah percakapan antargawai yang seharusnya dicas bukan di-tcas. Pertanyaan tersebut terjawab di panel keempat ketika tokoh Gawai Hitam mencambuk Gawai Putih dengan cas dan menimbulkan efek bunyi /tcas/.

Apabila dilihat dari hal seharusnya, gawai yang lemah seharusnya dicas untuk mengisi energi gawai tersebut. Akan tetapi, dalam Gambar 2 justru terjadi penambahan bunyi / $t$ / sehingga menjadi /tcas/ untuk menimbulkan efek suara benda yang dicambuk. Dalam gambar ini, Gawai Putih dicambuk menggunakan kabel cas sehingga menimbulkan suara /tcas/.

Gambar 2 menunjukkan adanya penambahan bunyi /t/ pada kata /cas/ untuk menimbulkan efek bunyi cambuk. Penambahan satu bunyi juga umum terjadi dalam komik @Tahilalats, misalnya penambahan bunyi /e/ pada kata /goblok/. Berdasarkan data yang dikumpulkan, ditemukan ada 5 edisi komik @Tahilalats 
Habib Safillah Akbariski: Permainan Bunyi dalam Penciptaan Humor Komik...

yang memanfaatkan penambahan bunyi /e/ di depan kata /goblok/ menjadi /egoblok/ untuk menimbulkan efek humor.

\subsubsection{Epentesis}

Epentesis adalah proses penambahan atau pembubuhan fonem di tengah kata (Badudu, 1985, hal. 83). Depdiknas (2008, hal. 377) menyatakan bahwa epentesis adalah penyisipan bunyi atau huruf ke dalam kata. Menurut Keraf (1984, hal. 136), epentesis adalah proses satu kata mendapat tambahan suatu fonem atau lebih di tengah-tengah kata. Dari ketiga pendapat tersebut dapat disimpulkan bahwa epentesis adalah penambahan fonem atau penyisipan di tengah kata. Gejala ini dapat dilihat pada contoh kata upama menjadi umpama, kapak menjadi kampak, peduli menjadi perduli.

Terdapat 8 data yang mengalami proses epentesis. Berikut ini disajikan data hasil penelitian beserta hasil analisis.

\section{Gambar 3}

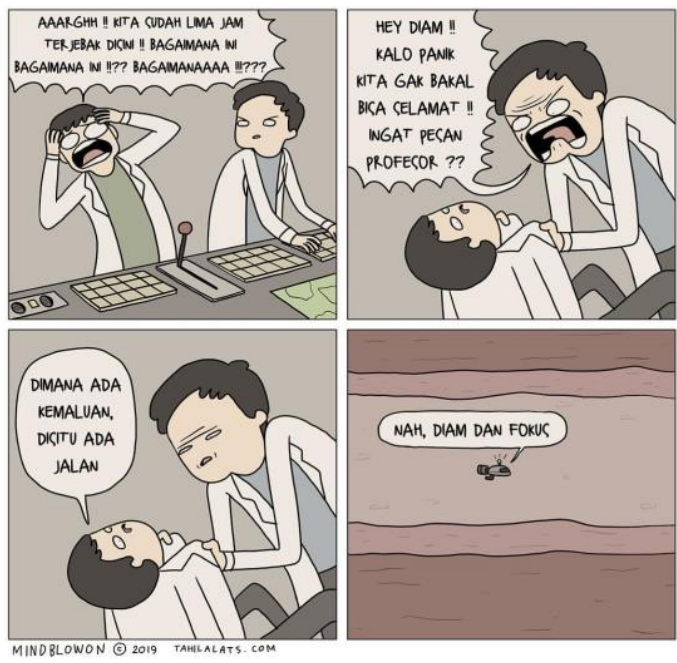

Peneliti 1: Aaarghh!! Kita sudah lima jam terjebak di sini!! Bagaimana ini bagaimana ini!!?? Bagaimanaaaa!!???

Peneliti 2: Hey diam!! Kalo panik kita gak bakal bisa selamat!! Ingat pesan profesor??

Peneliti 1: Di mana ada kemaluan, di situ ada jalan.

Peneliti 2: Nah, diam dan fokus.

Percakapan pada Gambar 3 menunjukkan adanya gejala adisi berupa proses epentesis. Gejala ini terjadi pada kata kemauan yang mengalami penyisipan bunyi /l/ menjadi kemaluan. Dalam percakapan di mana ada kemaluan, di situ ada jalan merupakan pelesetan dari di mana ada kemauan, di situ ada jalan. Peribahasa tersebut memiliki arti seseorang yang mempunyai niat dan kemauan yang kuat apabila ada kesulitan menghadang pasti akan mendapatkan kemudahan.

Humor pada Gambar 3 tercipta karena adanya proses penambahan bunyi /// pada kata kemauan menjadi kemaluan. Gambar 3 menceritakan tentang dua orang peneliti yang sedang tersesat sewaktu menjelajahi suatu wilayah. Pada awalnya kita dibuat bingung mengenai keberadaan dua orang peneliti ini. Akan tetapi, hal tersebut terjawab ketika Peneliti 1 mengatakan kata kemaluan didukung oleh gambar panel keempat yang menggambarkan keberadaan mereka seperti sedang berada dalam bagian kemaluan. Pemanfaatan gambar dan permainan bunyi pada gambar tersebut menciptakan humor bagi para pembaca.

Selain memelesetakan kata dalam peribahasa, komik Tahilalats juga memanfaatkan penambahan bunyi di tengah kata yang selanjutnya membentuk kalimat untuk menciptakan humor seperti pada Gambar 4.

\section{Gambar 4}

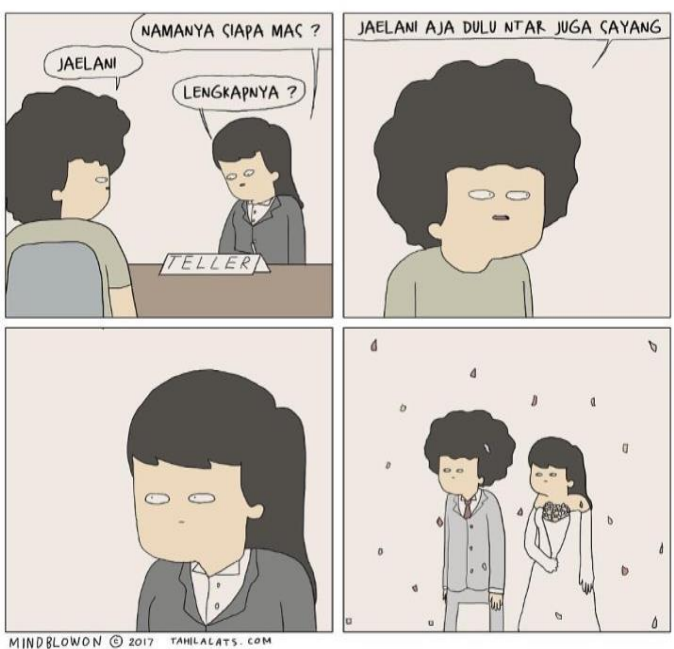

Teller: Namanya siapa, Mas?

Laki-Laki: Jaelani.

Teller: Lengkapnya?

Laki-Laki: Jaelani aja dulu ntar juga sayang. 
Habib Safillah Akbariski: Permainan Bunyi dalam Penciptaan Humor Komik...

Terdapat pemanfaatan permainan bunyi tataran epentesis pada Gambar 4. Hal tersebut dapat dilihat dalam percakapan jaelani aja dulu ntar juga sayang. Dalam kalimat tersebut, terdapat penambahan bunyi /e/ pada kata jalani menjadi jaelani. Penyebab penambahan bunyi /e/ adalah untuk menimbulkan humor. Motif yang terjadi karena Laki-Laki ingin menggombali Teller di hadapannya. Penambahan bunyi /e/ tersebut menimbulkan efek humor dalam Gambar 4. Terlebih, hal tersebut didukung oleh panel keempat dalam gambar yang menunjukkan bahwa LakiLaki dan Teller mengunakan baju pengantin.

\subsubsection{Paragog}

Paragog adalah proses penambahan bunyi di akhir kata (Badudu, 1985, hal. 63). Gejala paragog dapat dilihat dari contoh kata lamp menjadi lampu, adi menjadi adik.

Berikut ini disajikan data hasil penelitian beserta hasil analisis.

\section{Gambar 5}

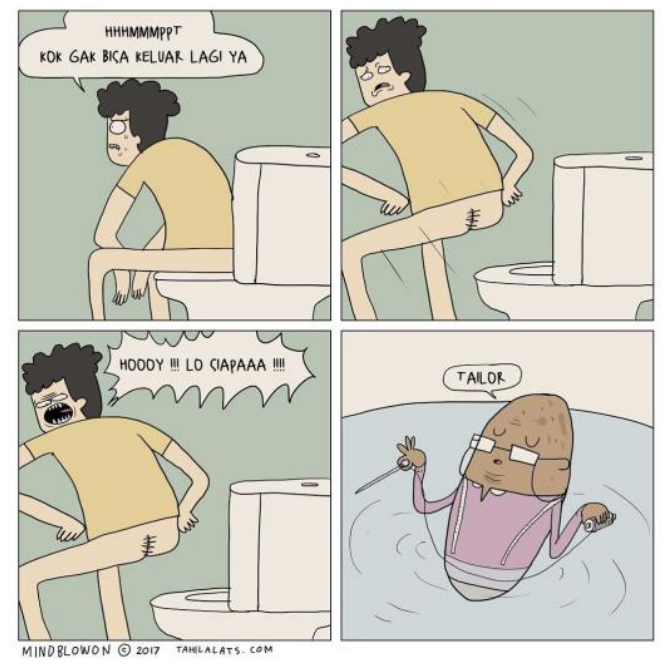

Laki-Laki: Hhhmmmppt kok gak bisa keluar lagi ya? Hoooy!!! Lo siapaaa!!!!

Tahi: Tailor.

Gambar 5 menggambarkan seorang pemuda yang sedang buang hajat, tetapi tiba-tiba hajat tidak bisa dikeluarkan lagi. Setelah dicek, ternyata dubur pemuda tersebut dijahit. Selanjutnya, muncullah tahi yang digambarkan seperti seorang nenek dengan memegang jarum jahit dan benang. Tahi tersebut menjawab bahwa dirinya adalah tailor ketika ditanya oleh pemuda.

Gambar 5 mengalami dua proses permainan bunyi, yaitu pelesapan bunyi di tengah dan penambahan bunyi di akhir kata. Proses pertama dapat kita amati dari kata tai yang mengalami pelesapan bunyi /h/ pada tengah kata. Kata tai umum digunakan dalam situasi nonformal. Secara umum, komik menggunakan bahasa nonformal dalam menciptakan humor. Oleh karena itu, kata tai dipilih untuk digunakan dalam konteks ini. Proses kedua adalah penambahan bunyi /lor/ setelah kata tai. Tailor merupakan bahasa Inggris dari kata penjahit.

Penambahan bunyi /lor/ setelah kata tai menimbulkan efek humor. Terlebih, hal tersebut ada hubungannya dengan dubur pemuda yang tidak bisa lagi buang hajat karena dijahit oleh tailor. Dalam konteks ini, terjadi permainan bunyi tataran paragog dan permainan semantis.

\subsubsection{Penambahan Bunyi di Awal dan Akhir}

Terdapat satu data yang mengalami proses penambahan bunyi di awal dan di akhir kata. Berikut ini disajikan data hasil penelitian beserta hasil analisis.

\section{Gambar 6}

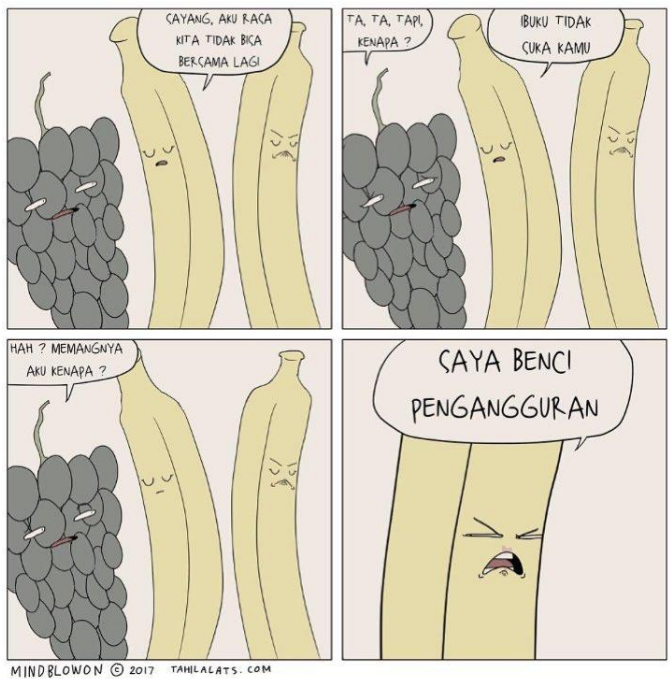

Pisang : Sayang, aku rasa kita tidak bisa bersama lagi.

Anggur : Ta, ta, tapi, kenapa?

Pisang : Ibuku tidak suka kamu.

Anggur: Hah? Memangnya aku kenapa? 
Ibu Pisang : Saya benci pengangguran.

Gambar 6 menceritakan Anggur dan Pisang yang sedang pacaran, tetapi tidak bisa bersama lagi karena sang Pisang tidak mendapatkan restu dari ibu Pisang yang benci pengangguran. Kata pengangguran berasal dari kata anggur yang mendapat bunyi /peng/ dan /an/. Selain memanfaatkan permainan bunyi, Gambar 6 juga memanfaatkan permainan semantik. Menurut KBBI (2016), pengangguran memiliki arti 'hal atau keadaan menganggur.' Teknik penambahan bunyi di awal dan di akhir dimanfaatkan untuk menciptakan humor. Selain memanfaatkan permainan bunyi berupa penambahan di awal dan di akhir, Gambar 6 juga memanfaatkan permainan bunyi dengan teknik repetisi. Hal tersebut terdapat dalam percakapan ta, ta, tapi, kenapa?

\subsection{Substitusi}

Substitusi adalah proses penggantian unsur bahasa oleh unsur bahasa yang lain dalam satuan yang lebih besar untuk memperoleh unsur-unsur pembeda atau untuk menjelaskan suatu struktur tertentu (Kridalaksana, Kamus Linguistik, 2011, hal. 229). Dalam hal ini, substitusi bunyi adalah suatu bunyi digantikan oleh bunyi yang lain. Apabila Kridalaksana berpendapat bahwa substitusi bunyi dimanfaatkan untuk menjelaskan suatu struktur tertentu, dalam konteks ini substitusi bunyi dimanfaatkan untuk menciptakan humor.

Terdapat beberapa 29 data yang mengalami substitusi bunyi. Berikut ini disajikan data hasil penelitian beserta hasil analisis.
Gambar 7

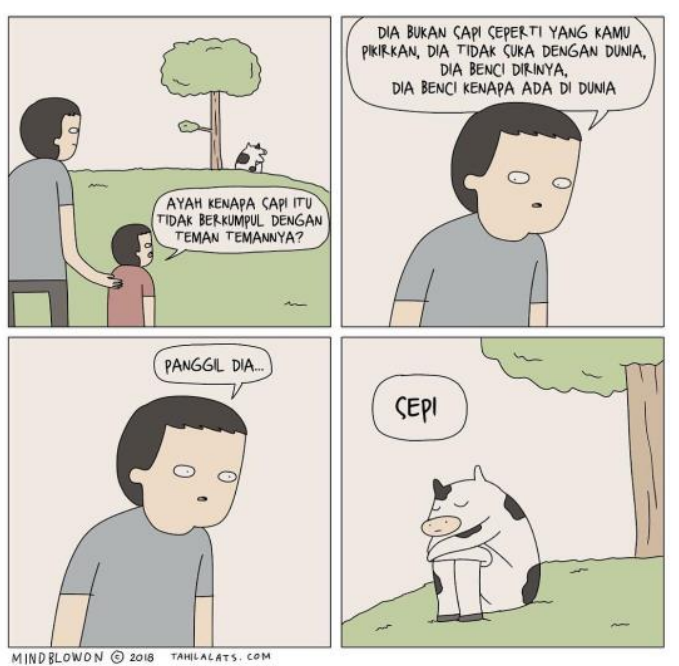

Anak: Ayah, kenapa sapi itu tidak berkumpul dengan temantemannya?

Ayah: Dia bukan sapi seperti yang kamu pikirkan, dia tidak suka dengan dunia, dia benci dirinya, dia benci kenapa ada di dunia. Panggil dia... Sepi

Kelucuan dibangun secara fonologis dengan mengganti bentuk sapi menjadi sepi. Dalam humor ini, fonem segmental /a/ diganti dengan fonem segmental /e/. Kelucuan ini juga melibatkan unsur semantis. Dalam KBBI (2016), sepi memiliki arti 'sunyi atau lengang,' sedangkan sapi memiliki arti 'binatang pemamah biak, bertanduk, berkuku genap, berkaki empat, bertubuh besar, dipiara untuk diambil daging dan susunya.'

Bentuk bahasa sepi dipilih untuk menggantikan sapi karena memiliki kemiripan bunyi yang mengandung kekontrasan makna. Akan tetapi, dalam komik tersebut menunjukkan adanya hubungan sapi dan sepi. Hal tersebut dapat dilihat dari percakapan antara anak yang bertanya kepada bapaknya mengenai seekor sapi yang duduk menyepi di bawah pohon. Sapi tersebut berada di tempat yang sepi karena tidak bersama temantemannya. Oleh karena itu, sang ayah menjuluki sapi tersebut dengan sebutan sepi. Berdasarkan hal tersebut, unsur humor dibangun secara fonologis dengan melibatkan unsur semantis.

Gambar 7 merupakan contoh permainan substitusi bunyi dalam bahasa Indonesia. Terdapat 11 data komik @Tahilalats yang 
Habib Safillah Akbariski: Permainan Bunyi dalam Penciptaan Humor Komik...

memanfaatkan permainan fonologis dengan teknik substitusi pada bunyi bahasa asing. Berikut ini disajikan data hasil penelitian beserta hasil analisis.

\section{Gambar 8}

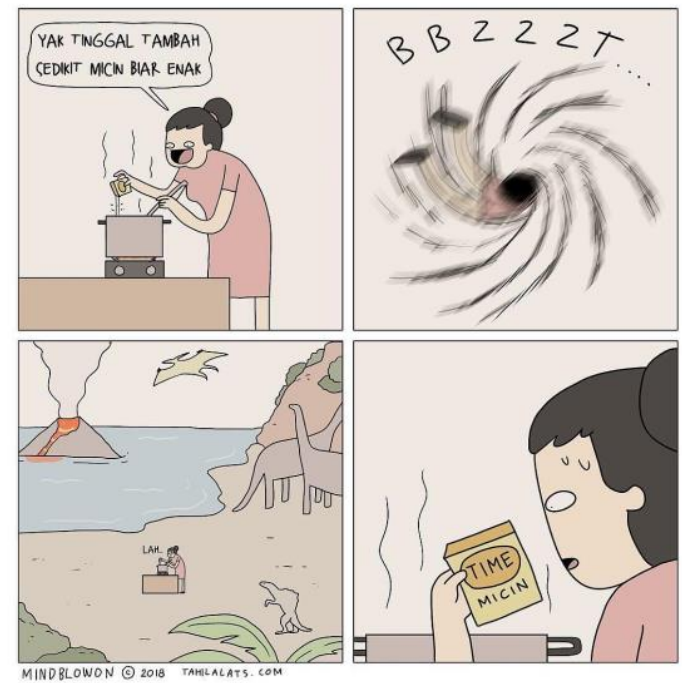

Gambar 8 menggambarkan seorang ibu yang tengah memasak. Ibu itu menabur sedikit micin dalam masakannya agar enak. Akan tetapi, setelah menabur micin dalam panci masakannya, ibu itu tiba-tiba tersedot ke dalam lubang waktu. Dalam sekejap, ibu itu berada di dekat sebuah gunung berapi dan terdapat beberapa ekor dinosaurus. Akhirnya, ibu tersebut membaca bungkusan micinnya dan heran membaca tulisan di bungkus tersebut yang bertuliskan time micin.

Gambar 8 memanfaatkan permainan bunyi dengan teknik substitusi untuk menciptakan humor. Bentuk bahasa micin merupakan hasil substitusi segmental dari bentuk asal machine. Pada kata micin terdapat substitusi bunyi /i/ terhadap /a/, /chine/ terhadap /cin/.

Substitusi bunyi terjadi bersamaan dengan permainan semantik. Micin memiliki arti vetsin yang lebih lanjut dijelaskan bahwa vetsin adalah bumbu tambahan untuk menyedapkan masakan berupa serbuk berwarna putih bersih, monosodium glutamat sebagai bahannya. Bumbu tersebut umum digunakan kalangan ibu-ibu untuk memasak. Lain halnya dengan machine yang merupakan bahasa Inggris dari mesin. Apabila melihat bagian pertama dari gambar, maka konteks yang dibangun adalah micin yang merupakan bumbu masak. Namun, apabila dilihat pada bagian 2, 3, dan 4, konteks yang dibangun adalah machine. Permainan bunyi dengan teknik substitusi dan permainan semantik yang berkaitan dengan konteks dalam gambar menjadi salah satu aspek yang menciptakan humor dalam komik @Tahilalats pada Gambar 8. Pemanfaatan substitusi bunyi terhadap bahasa asing juga terdapat pada Gambar 9.

\section{Gambar 9}

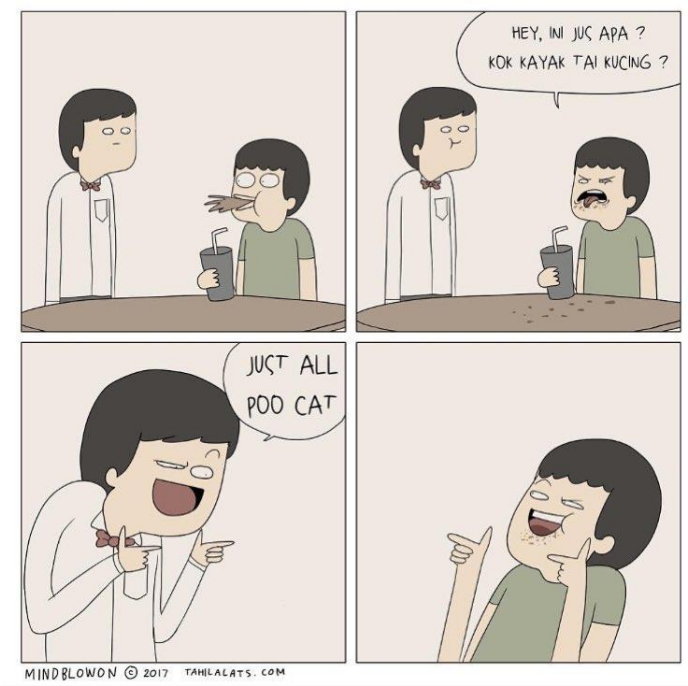

O1: Hey, ini jus apa? Kok kayak tai kucing?

02: Just all poo cat.

Gambar 8 menceritakan seorang pelanggan (O2) yang sedang meminum jus yang disediakan oleh sang pelayan (O1). Akan tetapi, pelanggan tersebut memuntahkan jus yang diminumnya karena memiliki rasa seperti tahi kucing. Akhirnya, sang pelayan menjawab bahwa yang diminum oleh sang pelanggan adalah just all poo cat yang memiliki kesamaan bunyi dengan jus alpukat. Substitusi bunyi pada bentuk bahasa tersebut dapat nyatakan sebagai berikut.

$$
\begin{aligned}
& \text { Just: Jus } \\
& \text { All: Al } \\
& \text { Poo: P } \underline{u} \\
& \text { Cat: Kat }
\end{aligned}
$$

Dapat dilihat bahwa terjadi penambahan bunyi /t/ pada kata jus, penambahan bunyi /l/ pada kata /al/, substitusi bunyi /oo/ terhadap /u/, dan substitusi bunyi /c/ terhadap /k/.

Permainan bunyi dengan teknik substitusi terhadap bahasa asing 
merupakan teknik yang paling banyak dimanfaatkan dalam penciptaan humor @Tahilalats. Selain permainan bunyi dengan teknik substitusi terhadap bahasa asing, komik @Tahilalats juga memanfaatkan substitusi bunyi yang terjadi pada saat seorang anak bicara. Contoh substitusi bunyi bahasa bayi ini terdapat dalam Gambar 10 di bawah ini.

\section{Gambar 10}

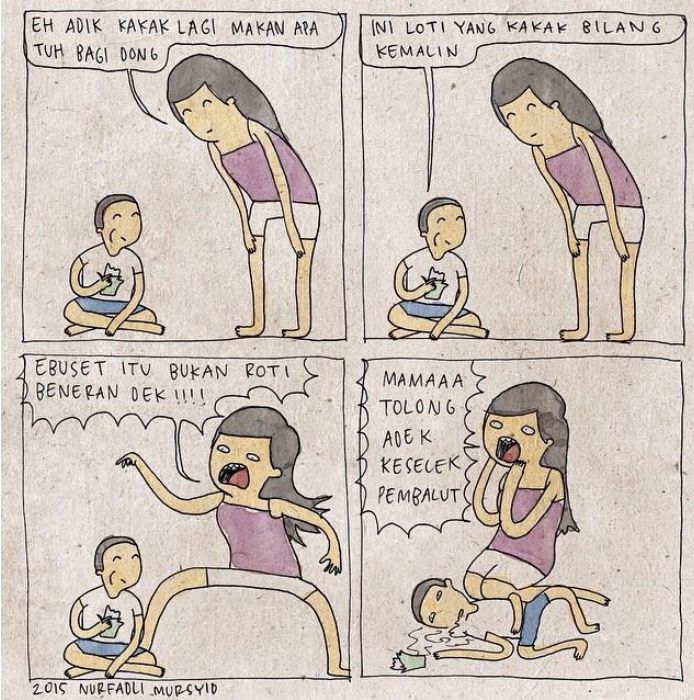

Kakak : Eh adik kakak lagi makan apa tuh? Bagi dong.

Adik : Ini loti yang kakak bilang kemalin.

Kakak : Ebuset itu bukan roti beneran dek!!! Mamaaa tolong adek keselek pembalut.

Gambar 10 menceritakan percakapan kakak dan adik. Dalam percakapan tersebut, sang adik berbicara dengan bahasa bayi. Substitusi bunyi terjadi pada kata loti dan kemalin. Pada kata loti terjadi substitusi bunyi / $/$ terhadap bunyi / $r /$ dari kata roti. Pada kata kemalin terjadi substitusi bunyi /l/ terhadap kata /r/ dari kata kemarin. Efek yang ditimbulkan dari substitusi bunyi /// terhadap /r/ ini menimbulkan efek percakapan bayi. Substitusi bunyi ini dimanfaatkan untuk menciptakan humor dalam komik @Tahilalats.

Selain itu, komik Tahilalats juga memanfaatkan substitusi bunyi /o/ terhadap /u/ seperti dalam kata terus menjadi teros, bunyi /e/ terhadap /i/ seperti pada kata anjing menjadi anjeng, dan bunyi /ai/ terhadap /e/ seperti dalam kata bangkai menjadi bangke.

\subsection{Repetisi}

Permainan bunyi dengan memanfaatkan teknik repetisi sebagai berikut.

\section{Gambar 11}

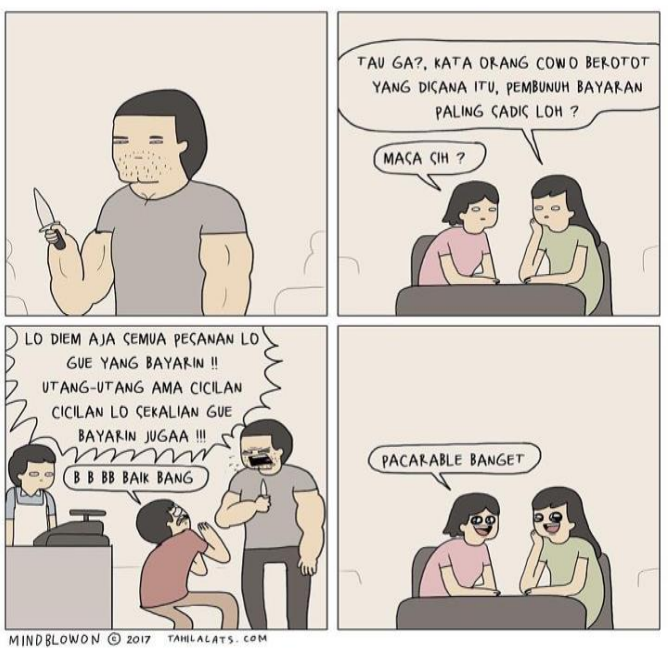

Cewek 1: Tau ga? Kata orang cowok berotot yang di sana itu, pembunuh bayaran paling sadis loh?

Cewek 2: Masa sih?

Cowok 1: Lo diem aja semua pesanan lo gue yang bayarin!! Utangutang ama cicilan-cicilan lo sekalian gue bayarin juga!!

Cowok 2: B B BB Baik Bang

Cewek $1 \&$ 2: Pacarable banget

Konteks percakapan di atas mengenai dua orang perempuan yang tengah membicara seorang pria berotot di dekat mereka yang membawa sebilah pisau. Pada bagian ketiga, terjadi percakapan antara Cowok 1 dan Cowok 2. Cowok 1 berbicara dengan tingkah seperti marah. Akan tetapi, isi percakapan Cowok 1 merupakan hal baik, yaitu ingin membayar semua pesanan, utang, dan cicilan Cowok 2. Pada bagian tiga ini kelucuan terjadi. Selain karena aspek pragmatik Cowok 1, percakapan Cowok 2 yang terbata-bata menimbulkan kelucuan. Bentuk terbatabata yang disampaikan oleh Cowok 2 merupakan salah satu pemanfaatan aspek fonologis tataran repetisi bunyi /b/ sebanyak tiga kali. Dalam hal ini, repetisi bunyi dimanfaatkan kreator untuk menciptakan efek terbata-bata. 
Habib Safillah Akbariski: Permainan Bunyi dalam Penciptaan Humor Komik...

Gambar 11 terdapat kontaminasi bahasa dalam proses penambahan fonem. Badudu (1985, hal. 51) berpendapat bahwa kontaminasi bahasa ialah suatu gejala bahasa yang diistilahkan dengan kerancuan. Berdasarkan pendapat dari Badudu dan Muslich mengenai kontaminasi bahasa, dapat disimpulkan bahwa gejala kontaminasi ialah bentukan kata yang tidak wajar disebabkan karena pencampuradukan dua unsur bahasa yang tidak wajar.

Gambar 11 terdapat kontaminasi bahasa pada bagian terakhir yaitu pacarable yang terdiri dari dua unsur bahasa pacar dan able. Fenomena ini umum terjadi. Salah satu pemanfaatan dua unsur bahasa dalam satu kata ini dalam penciptaan humor. Penambahan fonem /able/ di akhir kata pacar merupakan bentuk paragog. Selain terdapat paragog, gambar tersebut juga memanfaatkan aspek reptisi bunyi sebagai salah satu aspek penciptaan humor.

Selain memanfaatkan repetisi bunyi konsonan, komik @Tahilalats juga memanfaatkan repetisi suku kata untuk menciptakan efek humor seperti pada gambar di bawah ini.

\section{Gambar 12}

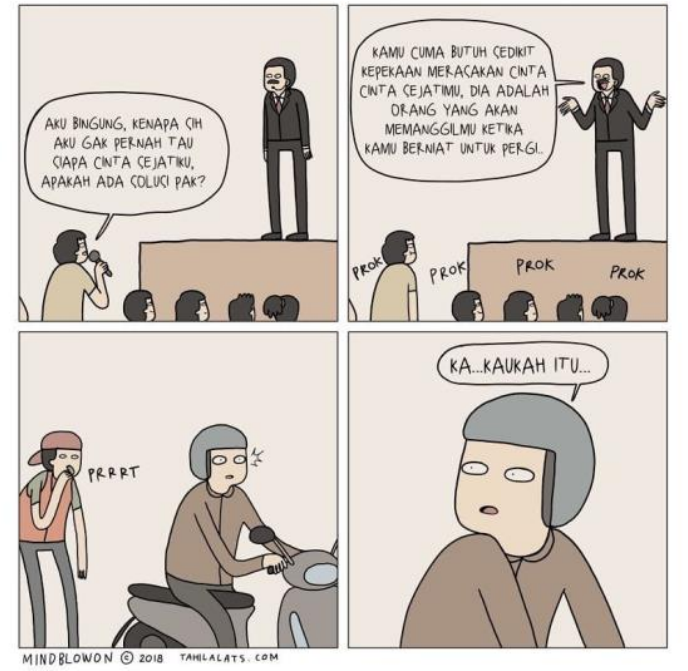

O1: Aku bingung kenapa sih aku gak pernah tahu siapa cinta sejatiku, apakah ada solusi, Pak?

O2: Kamu cuma butuh sedikit kepekaan merasakan cinta sejatimu. Dia adalah orang yang akan memanggilmu ketika kamu berniat untuk pergi.
O3: Prrrttt.

O4: Ka.....Kaukah itu....

Terdapat repetisi bunyi suku kata pada gambar 12. Repetisi tersebut terjadi pada kata kau bunyi /ka/ yang mengalami repetisi sebanyak 1 kali.

Jenis repetisi bunyi yang terakhir adalah repetisi kata seperti pada gambar 13 .

\section{Gambar 13}

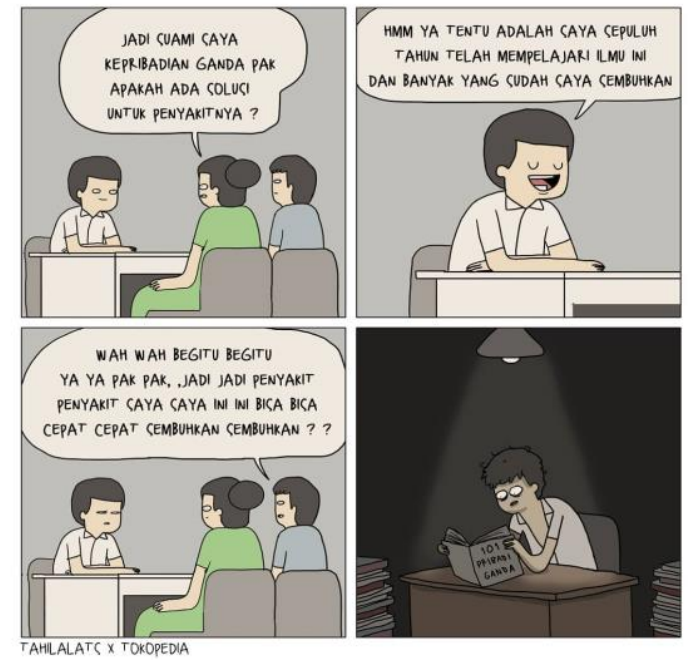

Istri : Jadi suami saya kepribadian ganda pak. Apakah ada solusi untuk penyakitnya?

Dokter : Hmm ya tentu ada lah saya sepuluh tahun telah mempelajari ilmu ini dan banyak yang sudah saya sembuhkan.

Suami : Wah wah begitu begitu ya ya pak pak. Jadi jadi penyakit penyakit saya saya ini ini bisa bisa cepat cepat sembuhkan sembuhkan?

Gambar 13 memanfaatkan permainan bunyi repetisi kata untuk menciptakan humor. Pada percakapan Suami, repetisi kata terjadi untuk menciptakan humor mengenai penyakit kepribadian ganda.

\subsection{Pencantuman Bunyi}

Pencantuman bunyi berkaitan dengan penghadiran bunyi-bunyi suprasegmental dan atau bunyi-bunyi yang dihasilkan oleh mesin, permainan musik, benda, dan teriakan. Pencantuman bunyi dalam hal ini dimanfaatkan untuk menciptakan humor. 


\section{Gambar 14}

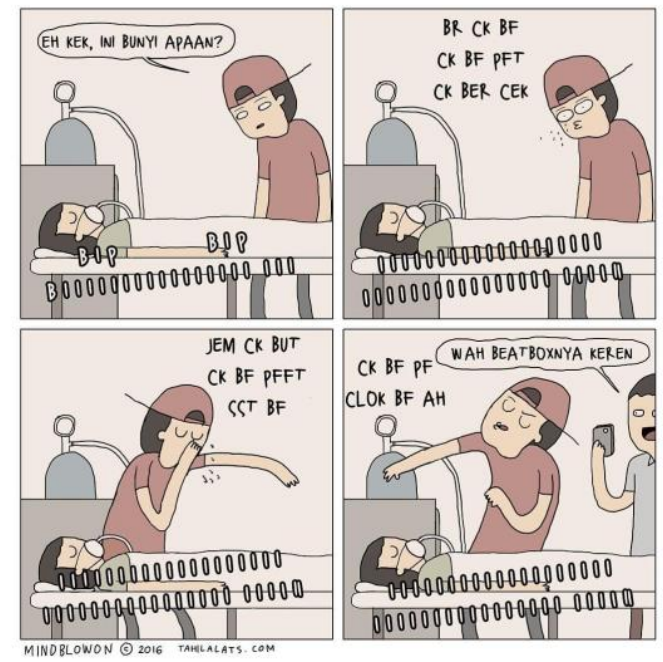

Gambar 14 mencantumkan bunyi mesin pendeteksi jantung yang mengisyratkan bahwa jantung pasien telah berhenti berdetak sehingga menimbulkan bunyi bip yang panjang. Bunyi "bip" tersebut dicantumkan oleh komikus untuk menimbulkan efek humor karena dilanjutkan oleh permainan suara dari cucunya. Komikus ingin menciptakan nuansa humor melalui efek suara yang dihasilkan dari mesin pendeteksi detak jantung dan permainan suara dari sang cucu sehingga menimbulkan permainan beatbox. Selain menimbulkan efek humor melalui suara yang dihasilkan benda, komikus@ @Tahilalats juga memanfaatkan efek suara yang dihasilkan oleh tenggorokan, seperti batuk atau suara menelan air ludah.

\subsection{Reduksi}

Gejala reduksi adalah peristiwa pengurangan fonem dalam suatu kata (Muslich, 2009, hal. 106). Gejala reduksi dapat dibagi menjadi tiga, yaitu aferesis, apokop, dan sinkop. Badudu (1985, hal. 63), Muslich ( (2009, hal. 106), dan Keraf (1989, hal. 135--136) berpendapat bahwa gejala penghilangan atau penanggalan fonem dapat dibagi menjadi tiga, yaitu aferesis, apokop, dan sinkop.

\subsubsection{Aferesis}

Aferesis adalah penanggalan bunyi di awal sebuah kata (Hadi, Soeratno, Ramlan, \& Wijana, 2003, hal. 123). Gejala ini dapat kita lihat pada contoh besok menjadi esok, ibunda menjadi bunda.

\section{Gambar 15}

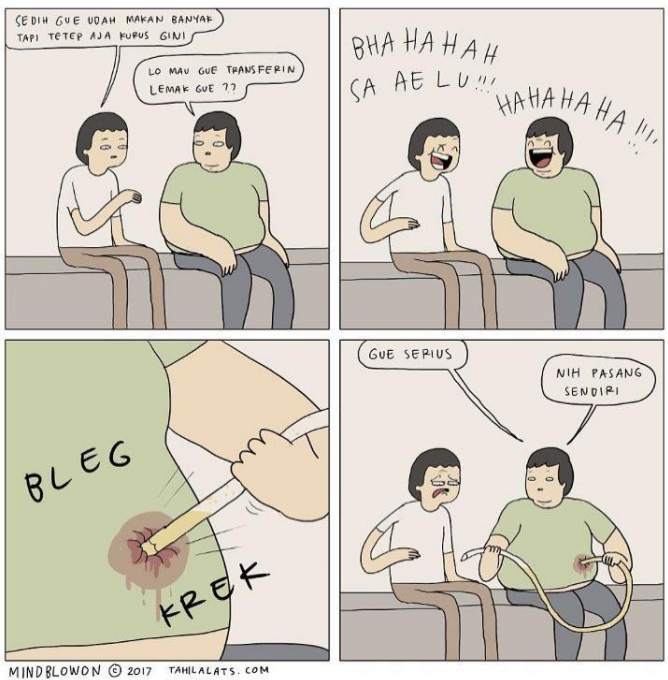

Gambar 15 terdapat proses aferesis pada kata sa yang mengalami penanggalan bunyi /bi/ pada awak kata bisa menjadi sa. Selain mengalami penanggalan pada awal kata, Gambar 15 juga mengalami penanggalan bunyi bunyi /j/ pada kata aje menjadi ae.

\subsubsection{Apokop}

Badudu (1985, hal. 63) dan Keraf (1984, hal. 136) berpendapat bahwa apokop adalah proses penghilangan atau penanggalan fonem pada akhir kata. Contoh kata yang mengalami apokop adalah buku menjadi buk dan samar menjadi sama.

\section{Gambar 16}

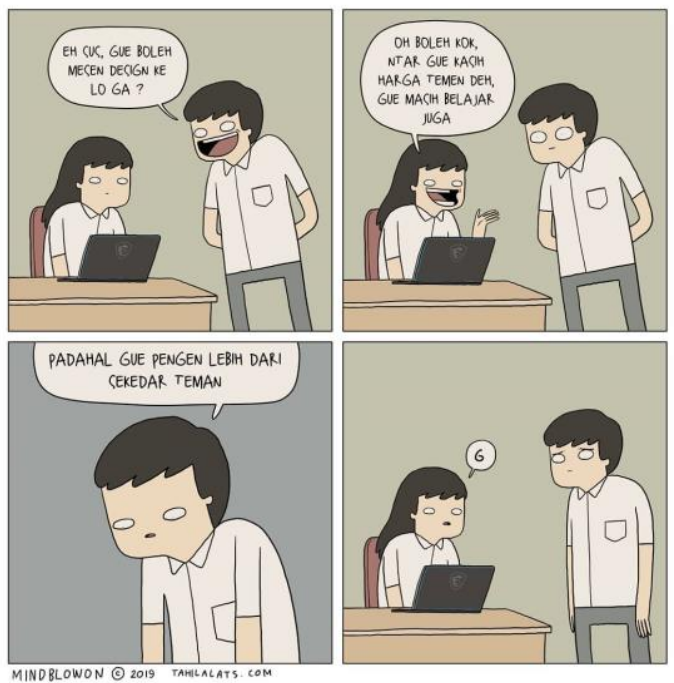


Habib Safillah Akbariski: Permainan Bunyi dalam Penciptaan Humor Komik...

Cowok: Eh sus, gue boleh mesen design ke lo ga?

Cewek: Oh boleh kok ntar gue kasih harga temen deh. Gue masih belajar juga.

Cowok: Padahal gue pengen lebhih dari sekedar teman.

Cewek: $\underline{\mathrm{G}}$.

Pada gambar 16 terdapat proses penghilangan bunyi di akhir kata. Proses tersebut terdapat pada bunyi $g$ yang mengalami menanggalan bunyi /ak/ pada kata gak.

\subsubsection{Sinkop}

Badudu (1985, hal. 63) berpendapat bahwa sinkop adalah penghilangan fonem di tengah kata. Hal tersebut sependapat dengan Keraf (1984, hal. 136) yang menyatakan bahwa sinkop adalah proses stuatu kata kehilangan satu fonem atau lebih di tengah-tengah kata. Contoh kata yang mengalami sinkop adalah tahu menjadi tau dan bahasa menjadi basa.

\section{Gambar 17}

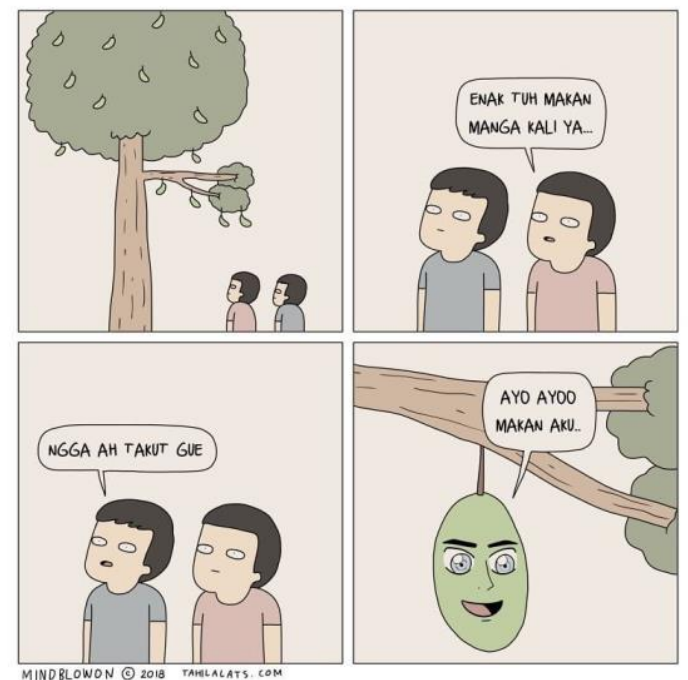

Orang 1: Enak tuh makan manga kali yak...

Orang 2: Ngga ah takut gue

Buah : Ayo ayoo makan aku..

Terdapat gejala penghilangan bunyi di tengah pada Gambar 17. Proses sinkop tersebut terjadi pada kata manga yang mengalami penghilangan bunyi $/ \mathrm{g} /$ dari kata mangga.

\subsection{Pemertahanan Bunyi}

Dari 129 data permainan bunyi yang ditemukan, terdapat 5 data yang memanfaatkan teknik pemertahanan bunyi. Pemertahanan bunyi merupakan teknik mempertahankan setengah sampai sebagian bunyi unsur pembentuk kata. Dalam hal ini, pemertahanan bunyi berkaitan dengan upaya membangun humor.

\section{Gambar 18}

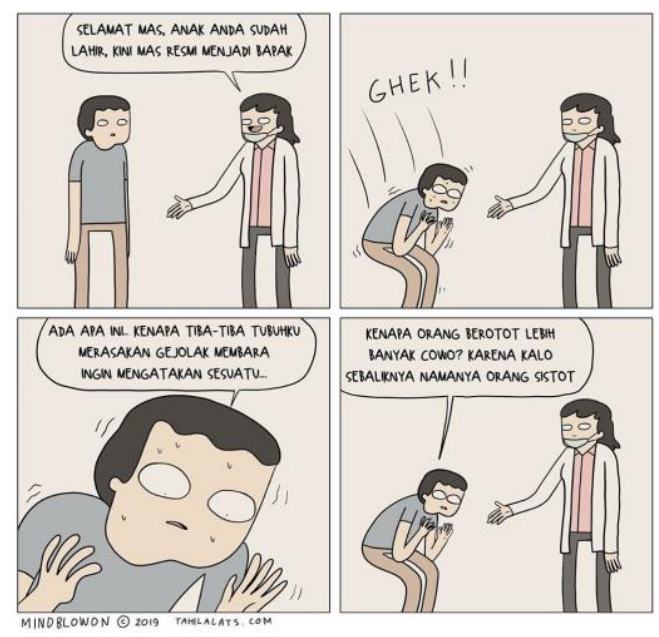

Dokter: Selamat mas. Anak anda sudah lahir. Kini mas resmi menjadi bapak.

Cowok: Ghek!! Ada apa ini.. Kenapa tiba-tiba tubuhku merasakan gejolak membara ingin mengatakan sesuatu... Kenapa orang berotot lebih banyak cowo? Karena kalo sebaliknya namanya orang sistot.

Bunyi yang dipertahankan pada Gambar 18 adalah bunyi silabel /tot/. Selain bunyi silabel /tot/, unsur pembentuk lainnya berubah-ubah. Pemertahanan bunyi dalam komik@ @Tahilalats@cenderung membandingkan dua hal atau lebih objek yang memiliki kesamaan bunyi. Dalam data ini, pemertahanan bunyi mengakibatkan hadirnya asosiasi makna. Hal tersebut dapat dilihat dari kata berotot yang bermakna memiliki otot dan pada kata sistot. Dalam konteks ini, kata berotot mengalami perubahan bentuk dari kata brotot yang terdiri dari silabel /bro/ dan /tot/. Bunyi yang dipertahankan adalah bunyi /tot/ seperti pada kata setelahnya, yaitu kata sistot yang terdiri dari silabel 
/sis/ dan /tot/. Bro dan sis merupakan sapaan yang berasal dari kata brother dan sister. Pemertahanan bunyi /tot/ dimanfaatkan dalam penciptaan humor @Tahilalats.

\subsection{Metatesis}

Metatesis adalah pergantian letak bunyi (huruf) dalam sebuah kata misalnya berantas jadi banteras, copot menjadi pocot (KBBI, 2016). Sebagai bagian dari permainan fonologis, metatesis dapat pula dijadikan aspek yang dapat menimbulkan efek humor.

\section{Gambar 19}

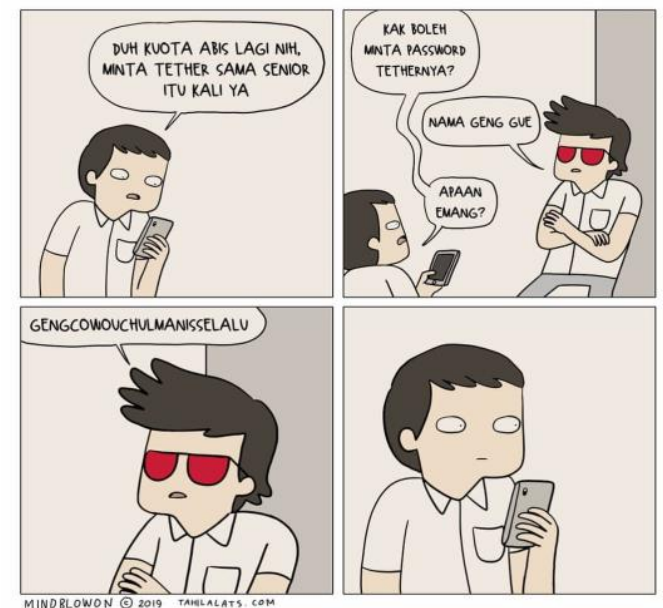

Cowok 1: Duh kuota abis lagi nih. Minta tether sama senior itu kali, ya. Kak, boleh minta password tethernya?

Cowok 2: Nama geng gue

Cowok 1: Apaan emang?

Cowok 2: Gengcowouchulmanisselalu.

Gambar 19 menunjukkan adanya proses metatesis pada kata uchul yang berasal dari kata lucuh dan mengalami proses penambahan bunyi /h/.

\subsection{Pemanjangan Bunyi}

Pemanjangan bunyi berkaitan dengan pemanjangan satu unsur bunyi pembentuk kata. Hal tersebut sengaja diciptakan untuk menghadikan efek penegasan, teriak, marah, panggilan, ratapan, dan ketakutan.

Berikut ini disajikan data hasil penelitian beserta hasil analisis.

\section{Gambar 20}

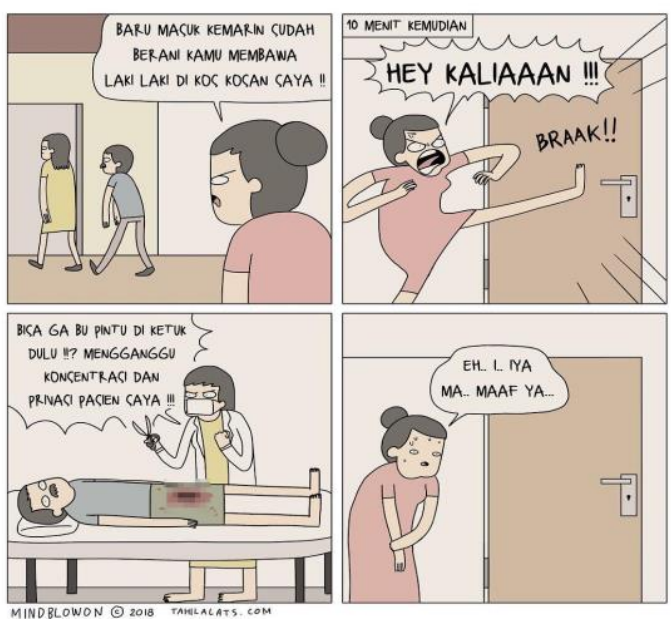

01: Baru masuk kemarin sudah berani kamu membawa laki-laki di koskosan saya!! Hey kaliaaan!!!

O2: Bisa ga bu pintu diketuk dulu!!? Menganggu konsentrasi dan privasi pasien saja!!!

O1: Eh.. I.. Iya ma..maaf ya...

Pada Gambar 21 terdapat proses pemanjangan bunyi pada kata kalian. Pemanjangan bunyi ini dimanfaatkan untuk menciptakan efek teriakan agar memberikan nuansa humor.

\subsection{Permainan Jeda}

Pemberian jeda berkaitan dengan penjedaan yang dilakukan di tengah unit pembentuk kata. Permainan jeda berakibat pada hilangnya kata awal dan memunculkan dua kata baru yang secara makna berbeda dari kata awalnya.

Gambar 21

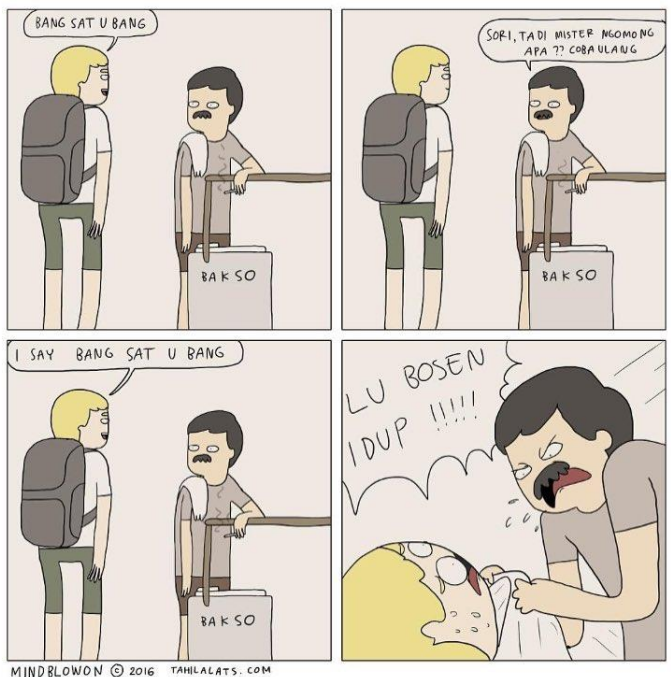


O1: Bang sat u Bang

O2: sori, tadi mister ngomong apa? Coba ulang

O1: I say bang sat u bang

O2: Lu bosen idup!!!!

Gambar 21 mengalami permainan jeda dalam penciptaan humor. Permainan jeda ini mengakibatkan pembentukan kata baru yang secara makna berbeda dengan kata awalnya. Selain itu, Gambar 21 juga mengalami penyingkatan yang umum terjadi pada kata lu menjadi $u$. Gambar 21 menceritakan tentang orang asing (01) yang ingin membeli semangkuk bakso (O2). Percakapan yang seharusnya terjadi adalah bang satu bang. Akan tetapi, permaina jeda menimbulkan makna yang baru yaitu bangsat lu bang. Penjedaan pada kata satu menjadi sat u menimbulkan perbedaan makna karena segmental /sat/ jadi bergabung dengan /bang/ sehingga menciptakan kata bangsat yang menimbulkan perbedaan makna.

\subsection{Kontraksi}

Kontraksi adalah proses penghilangan satu fonem atau lebih (Badudu, 1985, hal. 64). Depdiknas (2008, hal. 729) berpendapat bahwa kontraksi adalah proses atau hasil pemendekan suatu bentuk kebahasaan. Menurut Kridalaksana (1992, hal. 163), kontraksi adalah proses pemendekan yang meringkas leksem dasar atau gabungan leksem. Hal tersebut sependapat dengan yang dinyatakan Tarigan (1985, hal. 106) bahwa kontraksi adalah proses penyingkatan, penyusutan, atau penciutan suatu fonem dalam kata tanpa terjadi perubahan makna kata tersebut. Berdasarkan empat pernyataan tersebut, dapat disimpulkan bahwa kontraksi adalah proses penyingkatan pada kata sehingga kata tersebut lebih pendek dari sebelumnya. Contoh kata yang mengalami kontraksi adalah tidak menjadi tak dan tidak akan menjadi takkan.
Gambar 22

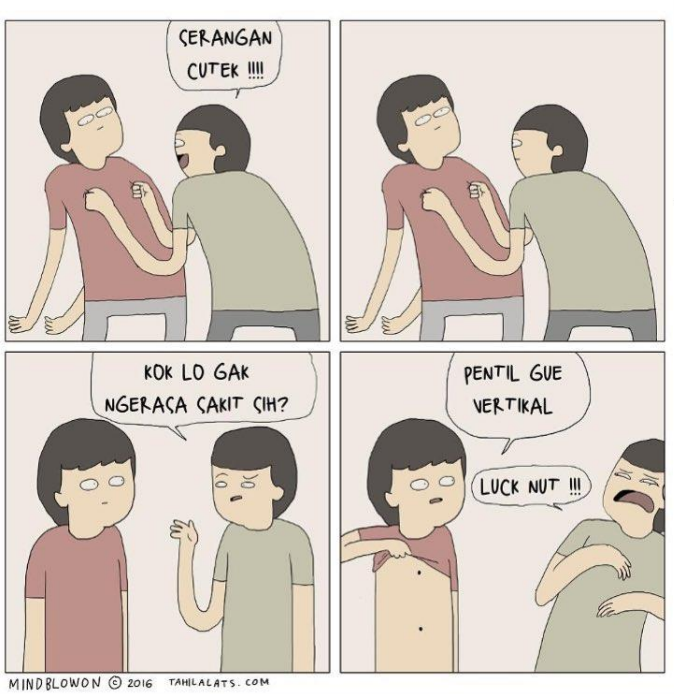

01: Serangan cutek!!!! Kok lo gak ngerasa sakit sih?

O2: Pentil gua vertikal.

O1: Luck nut!!!

Terdapat gejala kontraksi pada data di atas dalam penciptaan humor. Hal tersebut terdapat pada kata cutek yang merupakan pemendekan dari bentuk bahasa cubit tetek.

\subsection{Interpretasi Data}

Hasil penelitian menunjukkan bahwa permainan bunyi merupakan salah satu aspek yang bisa dimanfaatkan untuk menciptakan humor. Hal tersebut sependapat dengan Wijana (2003, hal. 131--139) bahwa unsur bunyi bahasa memiliki potensi membangun humor. Potensi tersebut dibangun dari proses kreatif mempermainkan unsur bunyi bahasa dengan menggunakan teknikteknik tertentu. Selain itu, Wijana juga berpendapat bahwa aspek bunyi dimanfaatkan dalam penciptaan humor karena aspek bunyi dalam satu kata memiliki potensi untuk mengubah makna.

Penelitian ini merumuskan ada 10 teknik permainan bunyi yang apabila dipecah terdapat 15 teknik permainan bunyi. Pada penelitian ini, terdapat 29 data yang memanfaatkan teknik substitusi. Berdasarkan hal tersebut, dapat disimpulkan bahwa teknik substitusi merupakan teknik yang paling banyak digunakan dalam penciptaan humor. Hal tersebut dapat disebabkan oleh timbulnya 
Habib Safillah Akbariski: Permainan Bunyi dalam Penciptaan Humor Komik...

makna baru dalam kata sehingga menimbulkan humor.

Wijana (2003: 131) berpendapat bahwa substitusi bunyi adalah penggantian unsur dalam kata sehingga tercipta sebuah kata baru yang hampir mirip secara bentuk atau bunyi serta memiliki makna yang berbeda. Berdasarkan pendapat tersebut, sejalan dengan salah satu metode penciptaan humor adalah dengan memelesetkan suatu kata. Pernyataan Wijana sejalan dengan pendapat Pradopo (1987) menyatakan bahwa tiga cara penciptaan humor, yakni penyimpangan bunyi, penyimpangan makna, dan pembentukan kata baru. Dalam teknik substitusi, ketiga hal tersebut terpenuh. Misalnya, sapi menjadi sepi terjadi tiga perubahan: (1) terjadi penyimpangan bunyi berupa substitusi bunyi /a/ menjadi /e/. (2) substitusi bunyi tersebut memengaruhi makna sehingga terjadi penyimpangan makna. Penyimpangan makna tersebut dapat kita lihat dari gambar sapi yang sedang menyendiri dan terdapat percakapan panggil dia sepi karena sapi tersebut duduk sendirian di bawah pohon. (3) terjadi pembentukan kata baru karena adanya substitusi bunyi /e/ sehingga sapi berubah menjadi sepi yang merupakan perubahan kata dari kata sebelumnya.

Penelitian yang dilakukan Sukardi menemukan ada 1 data yang memanfaatkan teknik pemanjangan bunyi. Dalam penelitian tersebut, pemanfaatan teknik pemanjangan bunyi merupakan pemanfaatan teknik yang paling sedikit dibanding 9 teknik lainnya. Lain halnya dengan penelitian ini yang menemukan ada 15 data yang memanfaatkan teknik pemanjangan bunyi. Hal tersebut dapat disebabkan karena perbedaan subjek penelitian. Subjek dalam penelitian yang dilakukan oleh Sukardi adalah meme Comic sedangkan dalam penelitian ini adalah komik @Tahilalats. Meme Comic hanya memiliki satu gambar tanpa adanya cerita atau panel-panel sehingga percakapan yang ditampilkan lebih singkat. Komik @Tahilalats berkonsep cerita sehingga satu gambar terdiri dari empat (panel) bagian. Oleh karena itu, percakapan dalam komik Tahilalats lebih kompleks daripada dalam meme Comic.
Pemanfaatan teknik pemanjangan bunyi banyak digunakan dalam komik @Tahilalats karena teknik pemanjangan bunyi dapat menimbulkan berbagai efek seperti efek teriak marah, teriak memerintah, bertanya, teriak meratapi, penegasan, panggilan, dan ketakutan. Efek-efek yang ditimbulkan tersebut umum digunakan dalam komik @Tahilalats sebagai salah satu aspek yang mendukung dalam penciptaan humor.

\subsection{Model Tuturan}

Model tuturan memanfaatkan teori SPEAKING oleh Dell Hymes. Aspek yang diambil adalah End, Act, Key.

\subsubsection{Tujuan}

Tujuan meliputi komponen hasil dan sasaran. Disadari atau tidak oleh penutur, dalam percakapan terdapat hasil akhir dan sasaran yang akan dicapai. Dengan demikian, apabila sebauh percakapan selesai, berdasar pada titik terminasi percakapan itu dapat disimpulkan sesuatu yang telah dicapai oleh masing-masing penutur. Ketercapaian itu bergantung pada derajat "negosiasi" yang dilakukan oleh para penutur.

Berdasarkan pernyataan di atas, dapat digarisbawahi bahwa pada akhir sebuah komik, terdapat semacam simpulan tentang yang dikatakan dan dilakukan oleh penutur dalam percakapan.

Tujuan tuturan dalam komik @Tahilalats dirumuskan bahwa P1

(Penutur 1) mengeluh sedangkan P2 (Penutur 2) memberikan solusi untuk menenangkan P1. Tujuan tuturan itu seperti digambarkan dalam Gambar 2 dan Gambar 3.

Tujuan tuturan P1 bertanya dan P2 memberikan jawaban atas pertanyaan P2 digambarkan dalam Gambar 4 dan Gambar 5. Motif bertanya bisa berbeda-beda, seperti karena keheranan (Gambar 5). Dampak bertanya yang ditimbulkan bisa menguntungkan pihak P2 sebagai penjawab seperti pada Gambar 4. Untuk pola bertanya dan menjawab, humor di dapat pada panel terakhir atau panel jawaban. 
3.12.2 Struktur Tindak Tutur

Bentuk tuturan yang disampaikan dalam komik @Tahilalats terdiri dari dua, yaitu tuturan disampaikan secara langsung dan secara tidak langsung. Tuturan secara langsung melalui percakapan antarpenutur. Bentuk tuturan langsung seperti yang digambarkan dalam Gambar 2, Gambar 3, Gambar 4, Gambar 5, dan Gambar 6. Tuturan secara tidak langsung melalui teks dalam produk, surat, dan papan pengumuman.

\subsubsection{Kunci}

Kunci merupakan komponen yang dimaksud sebagai cara tindak tutur dilakukan, misalnya dengan santai, serius, sewajarnya, ironis, atau dengan cara yang lain. Kunci juga meliputi unsur-unsur suprasegmental dan nonverbal seperti gerakan tubuh, cara bersikap, ekspresi, dan nada.

Komponen suprasegmental dimanfaatkan dalam penciptaan komik @Tahilalats. Hal tersebut dapat dilihat dari 129 data yang dianalisis terdapat 15 data yang memanfaatkan teknik pemanjangan bunyi. Teknik tersebut dimanfaatkan untuk menyatakan tuturan berteriak.

Komponen nonverbal berupa ekspresi juga dimanfaatkan penutur maupun lawan tutur seperti yang digambarkan dalam Gambar 15. Penutur P1 dan P2 tampak mengekspresikan wajah tertawa yang digambarkan pada panel 2. Hal tersebut didukung juga dengan pencantuman suara tertawa. Ekspresi jijik dan terkejut juga digambarkan dalam panel ke empat.

\section{SIMPULAN}

Penciptaan humor pada era digital mengalami perkembangan yang signifikan. Pemanfaatan aspek bahasa yang berkaitan dengan teknologi dan informasi menjadi salah satu bukti perkembangan humor. Jangkauan dari penikmat humor menjadi lebih luas karena kehadiran pelbagai media digital yang dimanfaatkan untuk menyampaikan humor.

Penelitian ini menunjukkan perkembangan permainan bunyi yang tidak hanya terpusat dalam ranah segmental, tetapi juga berkembang pada ranah suprasegmental. Penelitian ini menghasilkan lima temuan teknik permainan bunyi, yaitu penambahan bunyi di awal dan di akhir, repetisi, pencantuman bunyi, metatesis, dan kontraksi.

Permainan bunyi dengan teknik substitusi merupakan jenis permainan bunyi yang paling banyak diaplikasikan dalam penciptaan humor. Hal tersebut disebabkan karena teknik pemelesetan kata merupakan teknik yang paling umum digunakan dalam penciptaan humor.

Penelitian ini merumuskan model tuturan yang digunakan dalam @Tahilalats. Model tuturan yang banyak digunakan dalam penelitian ini bertujuan menenangkan lawan tutur. Proses mencapai tujuan tersebut dilakukan melalui kegiatan bertanya dan menjawab. Motif terjadinya tuturan dapat berbeda-beda seperti karena keheranan. Dampak yang ditimbulkan bisa menguntungkan pihak P2 sebagai penjawab.

Struktur tindak tutur dalam komik @Tahilalats disampaikan melalui tuturan langsung dan tidak langsung. Tindak tutur langsung terjadi antarpenutur. Tidak tutur tidak langsung terjadi melalui media surat, produk, pesan singkat, atau papan pengumuman.

Komponen yang dimanfaatkan dalam tuturan dilakukan karena maksud tertentu. Misalnya, santai, seriusa, ironis, atau lainnya. Kunci yang digunakan dalam tuturan komik @Tahilalats meliputi unsur suprasegmental dan nonverbal. Pemanfaatan unsur suprasegmental dapat dilihat berdasar pada 15 data yang memanfaatkan teknik pemanjangan bunyi. Komponen nonverbal berupa ekspresi dimanfaatkan penutur dan lawan tutur. Pemanfaatan unsur ekspresi menjadi sangat penting karena @Tahilalats menggunakan gambar sebagai salah satu media dalam menyampaikan humor.

Kemunculan berbagai akun komik bergenre humor dapat menjadi bahan kajian teraktual dalam bidang linguistik. Pada akhirnya, penelitian linguistik tidak lagi hanya berpusat pada kajian teks dalam buku saja melainkan juga teks-teks digital. Penelitian ini dapat menjadi referensi bagi peneliti-peneliti selanjutnya berkaitan dengan penciptaan humor bidang fonologi. Terlebih lagi, dalam penelitian ini menemukan beberapa teknik permainan bunyi baru dalam penciptaan humor 
Habib Safillah Akbariski: Permainan Bunyi dalam Penciptaan Humor Komik...

sekaligus menginterpretasi teknik permainan bunyi yang paling sering digunakan.

Penelitian ini diharapkan mampu menjadi referensi kajian linguistik. Selanjutnya, hasil dari penelitian dapat dijadikan bahan pengembangan bidang kajian bahasa, sastra, dan pengajaran. Contoh yang paling dekat pengembangan dalam bidang pengajaran adalah penelitian ini dapat dijadikan bahan referensi dalam mengembangkan materi ajar anekdot.

\section{DAFTAR PUSTAKA}

Badan Pengembangan Bahasa dan Perbukuan. (2016). Kamus Besar Bahasa Indonesia Edisi V.

Badudu, J. S. (1985). Pelik-Pelik Bahasa Indonesia. Bandung: Pustaka Prima.

Bell, N., \& Pomerantz, A. (2016). Humour in the Classroom. A Guide for Language Teachers and Educational Researchers. New York: Routledge.

Brown, G., \& Yule, G. (1983). Discourse Analysis. Cambridge: Cambridge University Press.

Depdiknas. (2008). Kurikulum Tingkat Satuan Pendidikan. Jakarta: Dikmenum.

Fatonah, N. (2017). "Permainan Bahasa dalam Wacana Humor pada Akun Meme Comic Indonesia di Instagram serta Implikasinya pada Pembelajaran Bahasa Indonesia di SMA". Skripsi FKIP Universitas Lampung.

Fauzan, M. (2017). "Gejala Bahasa Prokem Dialek Tega di Lingkungan Remaja Desa Kalisapu Kecamatan Slwai Kabupaten Tegal". Skripsi FKIP Universitas Muhammadiyah Purwokerto.

Hadi, S., Chamamah, S., Ramlan, M., \& Wijana, I. (2003). "Perubahan Fonologis Kata-Kata Serapan dari Bahasa Arab dalam Bahasa
Indonesia". Jurnal Humaniora, Vol. 15, No. 2, hlm. 121--132.

Hendarto, P. (1990). Filsafat Humor. Jakarta: Karya Megah.

Hermintoyo, M. (2011). "Aspek Bunyi sebagai Sarana Kreativitas Humor". Kajian Sastra: Jurnal Bidang Kebahasaan dan Kesusastraan, Vol. 35, No 1, hlm. 14-27.

Hidayah, A. (2012). "Wacana Humor Tertulis dalam Bahasa Indonesia: Suatu Wacana Rekreatif". Jurnal SAWERIGADING, Vol. 18, No.1, hlm. 47--58.

Holmes, J. (2006). An Introduction to Sociolinguistics. London: Routledge.

Hymes, D. (1974). Foundations of Sociolinguistics. An Ethnographic Approach. Philadelphia: $U$ of Pennsylvania.

Irfansyah, N., \& Sumarlan, S. (2017). "Implikatur Wacana Humor Gelar Wicara Ini Talkshow di Net TV". Bahastra: Jurnal Bahasa dan Seni, Vol. 37, No.1, hlm. 49-221.

Keraf, G. (1984). Linguistik Bandingan Historis. Jakarta: PT. Gramedia.

Keraf, G. (1989). Tata Bahasa Indonesia Deskriptif. Jakarta: Grasindo.

Kridalaksana, H. (1992). Pembentukan Kata dalam Bahasa Indonesia. Jakarta: PT. Gramedia Pustaka.

Kridalaksana, H. (2011). Kamus Linguistik. Jakarta: PT. Gramedia Pustaka.

Kurniawan, Y. (2018). "Teknik Penciptaan Humor dalam Komik Setrip Tahilalats di Webtoon". Tesis Universitas Diponegoro.

Martin, R. (2007). The Psycology of Humor: An Integrative Approach. Burlinton: Elsevier Academic Press. 
Habib Safillah Akbariski: Permainan Bunyi dalam Penciptaan Humor Komik...

Moleong, L. J. (2005). Metodologi Penelitian Kualitatif. Bandung: Remaja Rosdakarya.

Muslich, M. (2009). Tata Bentuk Bahasa Indonesia. Jakarta: Bumi Aksara.

Pradopo, R. D., \& dkk. (1987). Humor dalam Bahasa Jawa. Yogyakarta: Proyek Penelitian Bahasa dan Sastra Indonesia dan Daerah.

Rahmanadji, D. (2007). "Sejarah, Teori, Jenis, dan Fungsi Humor". Jurnal Bahasa dan Seni, Vol. 35, No. 2, hlm. 213--221.
Sukardi, Ighfir, M., Sumarlan, \& Martanto, S. (2019). "Upaya Membangun Humor dalam Wacana Meme melalui Permainan Bunyi (Kajian Semantik)". Hasta Wiyata: Jurnal Pendidikan Bahasa dan Sastra Indonesia, Vol. 2, No.1, hlm. 40--54.

Tarigan, H. G. (1985). Pengajaran Semantik. Bandung: Angkasa.

Wijana, I. (1995). Wacana Kartun dalam Bahasa Indonesia. Yogyakarta: FIB UGM.

Wijana, I. (2003). Kartun: Studi tentang Permainan Bahasa. Yogyakarta: Penerbit Ombak. 
Habib Safillah Akbariski: Permainan Bunyi dalam Penciptaan Humor Komik... 